Мартинюк Р. Президент і виконавча влада: співвідношення інститутів у практиці сучасних республік. Право України. 2020. № 3. С. 256-269.

УДК $342(100)$

\title{
ПРЕЗИДЕНТ І ВИКОНАВЧА ВЛАДА: СПІВВІДНОШЕННЯ ІНСТИТУТІВ У ПРАКТИЦІ СУЧАСНИХ РЕСПУБЛІК
}

\begin{abstract}
Анотація. Модель співвідношення глави держави і виконавчої влади багато в чому визначає сутність форми правління. Кожна республіканська форма правління встановлює притаманний їй спосіб співвідношення президента 3 виконавчою владою. У сучасних республіках суттєві відмінності виявляють як спосіб поєднання президента з виконавчою владою, так і ступінь цього поєднання. Організація державної влади в республіках із президентською і парламентарною формами правління втілює два альтернативні способи співвідношення президента 3 виконавчою владою. Якщо у президентській республіці президент поєднаний із виконавчою владою структурно й очолює систему іiі органів, то в парламентарній республіці президент максимально дистанційований від виконавчої влади. У змішаній республіці президент виведений за межі виконавчої влади структурно, однак суттєво інтегрований до неї функціонально. В основі різних способів співвідношення президента з виконавчою владою лежать несхожі доктринальні підходи до розуміння функціональної природи президента та його ролі в державному механізмі. Пошуками оптимального структурного та функціонального співвідношення президента 3 виконавчою владою позначена вся історія розвитку республіканської форми правління. Результати цього пошуку відбиває розмаїття сучасних республік. Однак i на сьогодні питання про співвідношення президента з виконавчою владою залишається предметом наукової дискусії. Наявний досвід республіканського державотворення засвідчує, що як структурне злиття президента з виконавчою владою, так i максимальне дистанціювання цих інститутів обмежують функціональний потенціал глави держави i зумовлюють зосередження виконавчої влади в одних руках. Питання про співвідношення президента 3 виконавчою владою набуває особливого значення для пострадянських республік, у яких намір посилити ефективність виконавчої влади засобом збільшення впливу на неї з боку президента в багатьох випадках було здійснено вкрай необережно. У більшості пострадянських республік, принаймні на початковому етапі їх розвитку, посилення конституційного статусу президента сягнуло критичної межі, спричинивши адміністративне підпорядкування йому системи органів виконавчої влади. Врешті-решт це спотворило природу прийнятої в них змішаної
\end{abstract}


республіканської форми правління і стало однією з найважливіших причин розвитку явища суперпрезидентства. Питання про співвідношення Президента України з виконавчою владою - ключове у визначенні напряму конституційної корекції вітчизняної форми правління. За будь-яких умов спосіб поєднання Президента України з виконавчою владою не повинен ні перешкоджати реалізації конституційних функцій Глави держави, ні перетворювати його на фактичного главу виконавчої влади.

Ключові слова: державний механізм; форма правління; президентська республіка; парламентарна республіка; змішана республіка; президент; виконавча влада; дуалізм виконавчої влади.

Відсутність серйозного концептуального підгрунтя інституту президента загальна риса, притаманна державознавству посткомуністичних країн. Як наслідок, у теорії державознавчих наук та реальній державній практиці країн, що утворилися на теренах колишнього Радянського Союзу, простежується тенденція невизначеності функціональної природи президента. Проте й у державознавстві розвинених країн питання про функціональну природу президента та зміст його компетенції є швидше предметом наукової дискусії, аніж єдиної для фахового середовища державно-правової парадигми. Організація державної влади у президентській, парламентарній та змішаній республіках втілює альтернативні доктринальні підходи до визначення функціональної природи президента та, зокрема, до питання про його співвідношення 3 виконавчою владою. Глава держави зберігав за собою виконавчу владу ще з тих часів, коли поділ влади тільки почав здійснюватися. Це пояснює, чому завжди певну частину повноважень президента за їх змістом можливо ототожнити або асоціювати з виконавчою владою'. Водночас спосіб компетенційного i функціонального поєднання президента 3 виконавчою владою в республіканських формах правління виявляє суттєві і принципові відмінності. Це ускладнює теоретичне вирішення питання про місце i роль президента у структурі державного механізму.

Історія розвитку республіканської форми правління позначена постійними пошуками оптимального структурного та функціонального співвідношення

\footnotetext{
${ }^{1}$ В Шаповал, Конституціійне право зарубіжних краӥн: підручник (Юрінком Інтер 2006) 286.
} 
президента 3 виконавчою владою. Результати цього пошуку визначальною мірою обумовили відмінності конституційно-правового статусу президента в сучасних республіках.

До появи у Франції в 1958 р. “повноцінної” змішаної республіки існували дві традиційні моделі співвідношення президента 3 виконавчою владою, відображені в теорії та практиці класичних - президентської і парламентарної республіканських форм правління. Президентську і парламентарну республіки характеризують два альтернативні i, по суті, “полярні” підходи до питання про співвідношення президента 3 виконавчою владою: у першому випадку (президентська республіка) президент очолює iі, у другому випадку (парламентарна республіка) президент максимально дистанційований від неї.

У змішаній республіці президент, з огляду на його статус координатораарбітра, структурно виведений за межі виконавчої влади, однак суттєво інтегрований до неї функціонально. Усе ж, попри наведені відмінності, саме явище поєднання президента 3 виконавчою владою характеризує всі сучасні республіканські форми правління² .

Історично сформована компетенція глави держави охоплювала насамперед такі сфери його діяльності, як представництво держави загалом, керівництво збройними силами та системою органів виконавчої влади. Однак у процесі становлення і розвитку сучасної демократичної держави відбулося суттєве функціональне і структурне дистанціювання їі глави, - як монарха, так i президента, - від виконавчої влади. Згадана тенденція в розвитку інституту глави держави найбільш виразно простежується у країнах із парламентарною формою правління. Цілком особливе співвідношення президента з виконавчою владою характеризує змішану республіканську форму правління. I тільки у президентській республіці ототожнення президента 3 виконавчою владою відображає “архаїчні” уявлення про його роль у державному механізмі основоположника класичної концепції поділу влади - Ш.-Л. Монтеск’є.

В основі різних способів співвідношення президента з виконавчою владою лежать несхожі доктринальні підходи до розуміння функціональної природи

2 В Шаповал, 'Виконавча влада в Україні у контексті форми державного правління (досвід після прийняття Конституції України 1996 року)’ (2016) 4 Право України 74. 
президента та його ролі в державному механізмі. Зокрема, притаманний державознавству Сполучених Штатів Америки підхід передбачає поєднання у статусі президента функцій глави держави і глави виконавчої влади. Відповідно до цього підходу, вважається, що баланс влад гарантує наділення президента повнотою виконавчої влади.

У президентській республіці президент як глава виконавчої влади поєднаний з нею і структурно, і функціонально. Він володіє повнотою кадрових повноважень у виконавчій галузі, і навіть за наявності посади прем'єр-міністра i скріплення з боку останнього актів президента, тут не виникає дуалізму виконавчої влади. У президентській формі правління організація керівної ланки в системі органів виконавчої влади одноосібна, а позиція іiі членів під час голосування має дорадчий характер. Як реальний глава виконавчої влади, президент самостійно визначає зміст урядової політики, а повноважність адміністрації президента ніяк не пов’язана з їі парламентською інвеститурою.

3 огляду на те, що у президентській формі правління у статусі президента поєднуються функції глави держави i глави виконавчої влади, його функціональна природа тут невизначена. У цьому простежується генетичний зв’язок президентської республіки з дуалістичною монархією.

У парламентарній республіці, що засвідчує зміст основних законів країн із цією формою правління, президент мінімально сполучений із виконавчою владою. Тут, з-поміж усіх республіканських форм правління, його дистанціювання від виконавчої влади найсуттєвіше. Він не поєднаний із нею ні структурно, ні загалом компетенційно.

Хоча у країнах із парламентарно-республіканською формою правління ступінь поєднання президента 3 виконавчою владою виявляє помітні формально-правові відмінності, вони не мають принципового значення. У парламентарній республіці взаємодія президента й уряду опосередкована інститутом контрасигнатури, у контексті застосування якого й повинні аналізуватися компетенційні взаємозв’язки цих суб'єктів. Контрасигнатура скріплення певних актів президента підписами прем’єр-міністра і (чи) профільного міністра як умова набуття цими актами чинності. Відмітна риса 
парламентарної республіки - поширення контрасигнатури на всі чи майже всі акти президента. Ця обставина зумовлює цілковиту “зв’язаність” його дій політичною волею прем’єр-міністра. Тому в парламентарній республіці президент не може самостійно здійснювати свою конституційну компетенцію.

Реалізацію ідеї дистанціювання президента від виконавчої влади в парламентарній республіці складно вважати вдалою. Обмеження впливу на виконавчу владу з боку президента неминуче спричиняє відповідне розширення компетенції прем’єр-міністра. По суті, концентрація виконавчої влади в руках прем’єр-міністра в парламентарній республіці підмінює небезпеку одноосібної президентської диктатури небезпекою диктатури вузько колегіальної. Загроза такої диктатури вирішальною мірою обумовлена саме відсутністю “сильного”, незалежного у своїх діях і протиставленого парламенту в сенсі партійної належності президента. У парламентарній формі правління потенційним суб’єктом цієї диктатури є прем’єр-міністр (він же - лідер парламентської більшості) й очолюваний ним уряд. Лише строкатість партійних систем у європейських країнах із парламентарною формою правління і породжувана нею відносна урядова нестабільність нівелюють потенційні авторитарні тенденції класичного парламентаризму.

У сенсі організації виконавчої влади змішана республіка виявляє принципову конститутивну перевагу над класичними типами республіканської форми правління. Характерна для неї модель співвідношення президента 3 виконавчою владою зумовлює дуалізм останньої. Дуалізм виконавчої влади унеможливлює iii зосередження в руках президента чи прем’єр-міністра. Отже, у змішаній республіці суттєво обмежено можливість зловживання виконавчою владою як із боку президента (ваду президентської республіки), так і прем’єрміністра (ваду парламентарної республіки).

Концепція змішаної республіки, на поточний момент розроблена в загальних рисах, описує главу держави (президента) як функціонально “нейтральний” елемент державного механізму. Функціонально “нейтральну” природу президента неможливо жорстко прив’язати до будь-якої з “розділених влад”. У змішаній республіці президент структурно виведений за межі 
виконавчої влади і водночас не утворює окремої галузі влади. Він відіграє роль координатора-арбітра, забезпечуючи узгоджену взаємодію вищих органів держави. У цій формі правління координаційно-арбітражна функція “титульна” складова компетенції президента і, відповідно, утворює основу його правового статусу. Водночас президент - ключовий, поряд 3 органом конституційної юрисдикції, охоронець конституційного ладу. Звідси інший важливий напрям його діяльності - гарантування конституційних цінностей. Отже, у змішаній республіці роль президента в державному механізмі пов’язана насамперед із його функціями гаранта та координатора-арбітра.

Доктринальний підхід, який визначає президента гарантом єдності державної влади та координатором-арбітром, унеможливлює його структурну чи навіть таку функціональну інтеграцію в будь-яку галузь влади, яка б могла спричинити у відповідній галузі його домінантну роль. Статус координатораарбітра, зокрема, робить неприпустимим ототожнення президента 3 виконавчою владою. Це суперечило б його посередницькій ролі в конфліктах між вищими органами держави і перешкоджало б реалізації принципу поділу влади. Президент може очолювати виконавчу владу або бути арбітром у системі поділу влади, але не може поєднувати обидві ролі. Тому навіть притаманний змішаній республіці дуалізм виконавчої влади не дає підстав ототожнювати з нею президента. Дуалістична організація виконавчої влади не наділяє президента адміністративними повноваженнями щодо системи іiі органів. Повнота цих повноважень належить прем’єр-міністру. У змішаній республіці співвідношення президента 3 виконавчою владою не може призводити до встановлення адміністративної залежності керівників їі органів від глави держави. Це усунуло б дуалізм виконавчої влади, відтак, спотворило б природу змішаної республіки.

Притаманний змішаній республіці дуалізм виконавчої влади передбачає

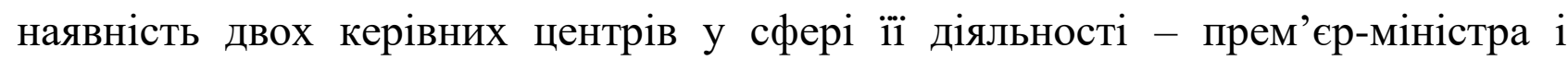
президента, поєднаних між собою не структурно, а функціонально. Співвідношення цих суб’єктів із виконавчою владою не однакове: якщо уряд $є$ iii вищим керівним органом, то президент поєднаний із виконавчою владою 
функціонально - через певний обсяг своїх виконавчих повноважень ${ }^{3}$. Такі повноваження, хоча й належать президенту, є виконавчими за своїм характером (юридичною природою). Водночас, попри реальне i безпосереднє функціональне поєднання президента 3 виконавчою владою, у змішаній республіці парламентська відповідальність уряду не призводить до дострокового припинення повноважень президента. Це засвідчує, що у змішаній республіці президент не є керівником виконавчої влади ${ }^{4}$. Дуалізм виконавчої влади не означає, що іiі різні сегменти підпорядковуються різним центрам - президенту або уряду ${ }^{5}$, і конституційно визначеним вищим органом виконавчої влади є уряд. У змішаній республіці президента, з огляду на характер його компетенції, неможливо ототожнити з жодною галуззю влади, i виконавчою зокрема.

Загальний для змішаних республік підхід до розподілу повноважень між президентом і прем'єр-міністром у виконавчій галузі полягає в тому, що хоча відповідні повноваження цих суб'єктів “переплітаються”, повноваження президента мають визначальний характер. Глава держави - президент відповідає переважно за вирішення стратегічних питань, контролює такі сфери державно-владної діяльності, як зовнішня політика, оборона, а прем'єр-міністр вирішує тактичні завдання і здійснює оперативне, повсякденне управління. Володіючи в низці випадків правом припиняти повноваження уряду, правом головувати на його засіданнях та відіграючи, фактично, відповідно до змісту своїх конституційних повноважень, керівну роль у сфері сумісної з урядом компетенції, у змішаній республіці президент справляє суттєвий вплив на діяльність виконавчої влади.

Сумісна компетенція президента й уряду відображає намагання як поєднати в організації виконавчої влади кращі риси президентської i парламентарної форм правління, так і уникнути їхніх вад. Позитивні риси дуалістичної організації виконавчої влади - висока функціональна ефективність

\footnotetext{
3 В Авер'янов, 'Виконавча влада в Україні: організація та розвиток інститутів' в Державотворення $i$ правотворення в Украӥні: досвід, проблеми, перспективи: монографія (Інститут держави і права ім. В. М. Корецького 2001) 139.

${ }^{4}$ Ф Ардан, Франциия: государственная система (Юридическая литература 1994) 73.

5 О Петришин, ‘Форма державного правління в Україні: до пошуку конституційної моделі' (2014) 8 Право Украӥни 109.
} 
уряду, яка суттєвою мірою $є$ наслідком впливу на його організацію та діяльність із боку президента, а також наявність достатньо самостійного у своїх рішеннях і діях прем'єр-міністра - ставленика парламентської більшості. Наслідком дуалістичної організації виконавчої влади є суттєва функціональна залежність президента від прем’єр-міністра (уряду). Президент Франції, наприклад, не може реалізувати низку своїх повноважень без офіційної пропозиції Уряду або попередніх консультацій із Прем’єр-міністром 6 . У Португалії в передбачених Конституцією випадках Президент здійснює свої повноваження за умови попереднього заслуховування думки Урядуㄱ. Тим самим дуалізм виконавчої влади забезпечує єдність державної політики, яку здійснюють два самостійні суб’єкти - президент та уряд.

Дуалістична організація виконавчої влади грунтується на усвідомленні спільної вади президентської та парламентарної форм правління зосередження виконавчої влади в руках одного суб'єкта - президента або, відповідно, прем’єр-міністра. У змішаній республіці цей дефект класичних республік усуває дуалізм виконавчої влади. Наявність двох керівних суб'єктів виконавчої влади - президента і прем’єр-міністра, жоден з яких компетенційно не домінує, за будь-якої їх партійної належності унеможливлює концентрацію виконавчої влади в руках одного з них.

Про реальне існування дуалізму виконавчої влади можна говорити лише за дотримання кількох принципових умов: наявності парламентської інвеститури уряду (схвалення програми діяльності уряду як умови його повноважності), відсутності у президента права на власний розсуд вирішувати питання про припинення повноважень уряду (прем’єр-міністра та міністрів уряду) та права скасовувати урядові акти, наявності у прем’єр-міністра дискреційного права скріплювати своїм підписом акти глави держави як умови набуття цими актами чинності. Поєднання таких обставин, як парламентський спосіб формування уряду, його парламентська інвеститура та дискреційна форма контрасигнації актів президента з боку прем’єр-міністра, відсутність у глави держави права на

\footnotetext{
${ }^{6}$ Конституция Французской Республики от 4 октября 1958 г. Ст.ст. 11, 12 в Конституции государств Европейского Союза (НОРМА-ИНФРА-М 1999) 667-668.

${ }^{7}$ Конституция Португальской Республики от 2 апреля 1976 г. Ст. 137. П. f в Конституции государств Европейского Союза (НОРМА-ИНФРА-М 1999) 557.
} 
власний розсуд здійснювати кадрові зміни у складі уряду та припиняти його повноваження, забезпечує достатню самостійність вищого органу виконавчої влади і, зокрема, прем’єр-міністра від президента.

Наведені умови пояснюють, чому повноцінний дуалізм виконавчої влади явище важкодосяжне. Державно-правовий досвід багатьох пострадянських республік засвідчив, що дуалізм виконавчої влади завжди виявляється суттєво зруйнованим внаслідок наділення президента нічим не обмеженим дискреційним правом припиняти повноваження прем’єр-міністра (уряду), а так само правом скасовувати урядові акти. Очевидно, що дуалізм виконавчої влади не може стати реальною характеристикою форми правління за умов адміністративного підпорядкування членів уряду президенту.

Хоча притаманна змішаній республіці дуалістична організація виконавчої влади передбачає керівну роль президента в певних сферах діяльності уряду, вона вимагає урівноваження впливу цих суб’єктів на рішення, що стосуються їх сумісної компетенції. Ухвалення цих рішень є наслідком досягнення компромісу між президентом й урядом. Згаданий компроміс забезпечує конституційна вимога скріплення підписом прем’єр-міністра і (або) відповідального міністра актів президента, що стосуються компетенції уряду. У П’ятій Французькій Республіці механізм взаємодії Президента й Уряду більш складний. Тут Президент має право головувати на засіданнях Уряду, на яких розглядаються питання, що стосуються їх сумісної компетенції, і підписувати відповідні акти. “Президент Республіки головує в Раді Міністрів”, “Президент Республіки підписує ордонанси й декрети, ухвалені Радою Міністрів” закріплено в Конституції Франції 1958 р. . Практика скріплення підписом президента актів уряду відображена і в Конституції Португалії 1976 р.9.

Загалом таким, що відповідає критеріям президентської форми правління, $\epsilon$ співвідношення президента i виконавчої влади в пострадянських президенціалізованих республіках. У багатьох країнах Східної Свропи й Азії неспроможність парламенту забезпечити появу стабільного уряду призвела до

\footnotetext{
8 Конституция Французской Республики от 4 октября 1958 г. Ст. 9; Ст. 13. Абз. 1 в Конституциии государств Европейского Союза (НОРМА-ИНФРА-М 1999) 667-668.

${ }^{9}$ Конституция Португальской Республики от 2 апреля 1976 г. Ст. 137. П. в в Конституциии государств Европейского Союза (НОРМА-ИНФРА-М 1999) 557.
} 
встановлення форми правління, у якій гарантом ефективності виконавчої влади став президент. Прагнення забезпечити урядову стабільність пояснює, чому в багатьох державах, які виникли після розпаду Радянського Союзу, центр політичної ваги був істотно зміщений у напрямі президенціалізму. Однак намір посилити ефективність виконавчої влади засобом збільшення впливу на неї 3 боку президента в багатьох випадках було здійснено вкрай необережно i спричинило перетворення президента на фактичного главу виконавчої влади.

Президент - “історичний наступник” монарха у структурі державного механізму $^{10}$, і важливо пам'ятати, що в абсолютній монархії глава держави уособлював державну владу як таку, i, насамперед, iї виконавчу галузь. Тому статус монарха визначали, зокрема, як глави виконавчої влади. Функціональну сполученість монарха з виконавчою владою виразно відображає організація державної влади в дуалістичній монархії - формі правління, перехідній від монархії абсолютної до парламентарної. Конституції i деяких сучасних парламентарних монархій зберігають “рудиментарні” положення про монарха як главу виконавчої влади. Монарх є главою виконавчої влади, зокрема, за змістом Конституції Люксембургу 1868 р. ${ }^{11}$. В Основному Законі Бельгії 1994 р. статус монарха визначено у главі під назвою "Про Короля і федеральний уряд"12. У Конституції Нідерландів 1983 р., де статус монарха закріплено у главі під назвою “Уряд”, встановлено, що “Уряд складається з Короля i міністрів"13. У Конституції Норвегії 1814 р. безпосередньо вказано, що “виконавча влада належить Королю”14. Відповідно до Конституції Данії 1953 р., “виконавчу владу здійснює Король”"15.

У процесі становлення сучасної республіканської державності характер влади монарха суттєвою мірою був перенесений на президента, для якого глава

\footnotetext{
${ }^{10}$ В Чиркин, Публичная власть (Юристь 2005) 91.

11 Конституция Великого герцогства Люксембург от 17 октября 1868 г. Ст. 76 <http://www.concourt.am> (дата звернення: 21. 11. 2019).

12 Конституция Бельгии от 17 февраля 1994 г. Глава III в Конституцчии государств Европейского Союза (НОРМА-ИНФРА-М 1999) 122-126.

${ }^{13}$ Конституция Королевства Нидерландов от 17 февраля 1983 г. Ст. 42. Ч. 1 〈http://constitution.garant.ru> (дата звернення: 21. 11. 2019).

14 Конституция Норвегии от 17 мая 1814 г. Ст. 3 <https://worldconstitutions.ru/?p=142> (дата звернення: 21. 11. 2019).

15 Конституция Королевства Дании от 5 июня 1953 г. Разд. 3 в Конституции государств Европейского Союза (НОРМА-ИНФРА-М 1999) 303.
} 
держави - монарх багато в чому послугував прототипом. Президент, зайнявши те місце, яке займав монарх, одночасно “успадкував” із деякими особливостями i багато його повноважень. “Монархічними” повноваженнями потрібно вважати, насамперед, повноваження глави президентської республіки у сфері організації та діяльності виконавчої влади.

Оскільки за монархічної форми правління глава держави був одноосібним органом, якому належала вся повнота виконавчої влади, первинно 3 монархом асоціювався і сам термін “глава виконавчої влади”. Пізніше глава президентської республіки здійснював у виконавчій галузі ті самі повноваження, що й монарх. Тому 3 цією галуззю стали ототожнювати i президента, поширивши на нього й термін “глава виконавчої влади”16.

Отже, повноваження президента у сфері організації та діяльності виконавчої влади - спадкова риса інституту монарха, з яким сучасний інститут президента зв’язаний генетично. Цей зв’язок пояснює, чому в історично першій сучасній республіканській формі правління - президентській республіці глава держави виявився і главою виконавчої влади.

Ідея суміщення статусів глави держави і глави виконавчої влади в одній особі сучасною державно-правовою теорією загалом сприйнята негативно. Згадане поєднання статусів розглядається як пережиток монархічної організації державної влади та як практика, що засвідчила свою хибність і згубність для демократії. Саме в цьому криється причина поступового зникнення класичних президентських республік. Розмежування повноважень глави держави і глави виконавчої влади та їх здійснення різними посадовими особами - принципова риса сучасної республіканської організації державної влади. Поєднання в одній посадовій особі статусів глави держави і глави виконавчої влади породжує нерозв’язну функціональну дилему. 'Це поєднання ролей, - зауважує С. Хангтінгтон, - $є$ спадок древньої практики; інститут президента був створений, як заявляв у 1787 р. Джефферсон, як виборна монархія. Цей інститут за задумом повинен був втілити в собі прерогативи британської

${ }^{16}$ С Серьогіна, Теоретично-правові та організаичійні засади функиіонування інституту президентства в Україні: монографія (Ксілон 2001) 10-11. 
Корони, i, відповідно, його політичні форми багато в чому суть форми двірцевої політики"17.

По суті, характерне для класичної президентської республіки наділення президента всією повнотою виконавчої влади - неподоланий пережиток монархізму. Природно, що відтворення цього регресивного й архаїчного атрибуту монархічної організації державної влади у республіканській формі правління спричиняє ті ж самі наслідки. Оцінюючи практику наділення глави держави повноваженнями глави виконавчої влади, В. Чиркін зазначає: “...Оголошення глави держави органом виконавчої влади було первинною невдачею концепції розподілу влад. Цей інститут ніколи не був лише виконавчим - ні юридично, ні фактично"18.

Ретроспективно в розвитку інституту президента простежується тенденція його структурно-функціонального дистанціювання від виконавчої влади. Водночас, оскільки генетичний зв'язок цього інституту з виконавчою владою зберігається за будь-якої республіканської форми правління, сама його функціональна природа вимагає певного включення в урядову діяльність. Оптимальне поєднання президента 3 виконавчою владою, вбачається, визначене концепцією змішаної республіки, однак практично втілене в небагатьох випадках. Президенціалізація і парламентаризація змішаної республіки руйнують притаманний їй дуалізм виконавчої влади і відтворюють той спосіб співвідношення президента з виконавчою владою, який характеризує президентську і, відповідно, парламентарну республіки. Лише у збалансованозмішаній республіці співвідношення повноважень президента і прем’єрміністра гарантує їх паритетний вплив на виконавчу владу.

Різні підходи до визначення конституційно-правового статусу президента обумовили суттєву варіативність республіканської форми правління. Вони ж засвідчують, що питання про співвідношення президента з виконавчою владою на сьогодні залишається предметом наукової дискусії. Природно, що це питання зберігає особливу актуальність i для багатьох пострадянських республік, для яких 3 особливою чіткістю постала дилема однакової

${ }^{17}$ С Хангтингтон, Политический порядок в меняющихся общеествах (Прогресс-Традиция 2004) 127.

${ }^{18}$ В Чиркин, Глава государства. Сравнительно-правовое исследование (Норма : Инфра-М 2010) 96. 
необхідності запровадження сильної влади президента за одночасного обмеження того ризику, який вона в собі таїть ${ }^{19}$. Теоретичні передумови вирішення цієї дилеми безпосередньо пов'язані 3 встановленням функціональної природи президента та його оптимального співвідношення 3 виконавчою владою. Зокрема, питання про спосіб співвідношення Президента України 3 виконавчою владою - ключове в конструюванні конституційноправового статусу Глави держави й безпосередньо конкретизує вибір форми правління в Україні. Будь-який варіант цього вибору не повинен заперечувати ідею суттєвої функціональної інтеграції Президента України у виконавчу владу ${ }^{20}$. Водночас модель компетенційних взаємозв'язків Президента України та Кабінету Міністрів України не повинна функціонально орієнтувати Главу держави на здійснення повноважень глави виконавчої влади, унеможливлюючи в такий спосіб його роль координатора-арбітра.

Висновки. Президент завжди функціонально інтегрований у виконавчу владу, тому певна частина його повноважень $є$ виконавчими за своїм характером. Водночас спосіб і ступінь поєднання президента 3 виконавчою владою в республіканських формах правління виявляють суттєві і принципові відмінності. Результати пошуку оптимального структурного та функціонального співвідношення президента з виконавчою владою засвідчили, що ні структурна інтеграція президента у виконавчу владу (президентська республіка), ні максимальне дистанціювання цих інститутів (парламентарна республіка) не забезпечують вдалу організацію виконавчої влади, оскільки породжують проблему зловживання нею. У парламентарній республіці зосередження партійного керівництва в уряді на тлі нерозвиненого громадянського суспільства і слабкості демократичних інститутів створює, по суті, такі ж загрози демократичним цінностям, як і концентрація виконавчої влади в руках глави президентської республіки. Лише у змішаній республіці паритетний вплив президента і прем’єр-міністра на виконавчу владу забезпечує ефективне вирішення окресленої проблеми. Очевидно й те, що характерний для

\footnotetext{
19 А Арутюнян, Институт президента Республики Армения (Сравнительно-правовой анализ) (Мхитар Гош 1996) 65.

${ }^{20}$ В Шаповал, Президент у механізмі здійснення державної влади (Національний інститут стратегічних досліджень 1995) 30.
} 
класичних республік спосіб співвідношення президента з виконавчою владою не дозволяє повноцінно розкрити функціональний потенціал глави держави як осьового й інтегративного елемента державного механізму.

Питання про місце і роль президента в державному механізмі та, зокрема, його співвідношення з виконавчою владою зберігає особливу актуальність для багатьох пострадянських республік. На пострадянському просторі у фаховому середовищі наявні непоодинокі спроби обгрунтувати і виправдати домінантне становище президента в державному механізмі, зокрема, його керівну роль щодо системи органів виконавчої влади. У пострадянських республіках втілення ідеї зверхності президента щодо інших вищих органів держави та фактичне поєднання в його особі функцій глави держави і глави виконавчої влади спричинили імітацію поділу влади та розвиток явища суперпрезидентства.

Спосіб співвідношення Президента України з виконавчою владою - один i3 найсуттєвіших елементів конституційно встановленої форми правління. Очевидно, що конституційні інструменти впливу Президента України на виконавчу владу повинні бути достатніми для ефективного забезпечення його конституційних функцій. Водночас вони не повинні спричиняти адміністративного підпорядкування Кабінету Міністрів України Главі держави, а відтак, - функціональної підміни з боку останнього вищого органу виконавчої влади.

\section{REFERENCES}

Bibliografhy

Authored books

1. Ardan F, Francija: gosudarstvennaja sistema [France: The State system] (Juridicheskaja literatura 1994) (in Russian).

2. Arutyunyan A, Institut prezidenta Respubliki Armeniya (Sravnitelno-pravovoy analiz) [Institution of the Presidency in the Republic of Armenia (Comparative legal study)] (Mhitar Gosh 1996) (in Russian). 
3. Serjoghina S, Teoretychno-pravovi ta orhanizatsiini zasady funktsionuvannia instytutu prezydentstva v Ukraini: monohrafiia [Theoretical framework and organizational principles of functioning of the institution of the Presidency in Ukraine] (Ksilon 2001) (in Ukrainian).

4. Hangtington S, Politicheskiy poryadok v menyayuschihsya obschestvah [Political Order in Changing Societies] (Progress-Traditsiya 2004) (in Russian).

5. Chirkin V, Glava gosudarstva. Sravnitel'no-pravovoe issledovanie [Head of State. Comparative law study] (NORMA: Infra-M 2010) (in Russian).

6. $\quad$ Chirkin V, Publichnaya vlast [Public Power] (Юрист 2005).

7. Shapoval V, Konstytutsiine pravo zarubizhnykh krain: pidruchnyk [The Constitutional law of foreign countries] (Yurinkom Inter 2006) (in Ukrainian).

8. Shapoval V, Prezydent u mekhanizmi zdiisnennia derzhavnoi vlady [The President in the mechanism of implementation of governmental authority] (Natsionalnyi instytut stratehichnykh doslidzhen 1995) (in Ukrainian).

\section{Edited books}

9. Averianov V, 'Vykonavcha vlada v Ukraini: orhanizatsiia ta rozvytok instytutiv' ['Executive power in Ukraine: organization and development of institutions'] v Derzhavotvorennia i pravotvorennia v Ukraini: dosvid, problemy, perspektyvy: monohrafiia (Instytut derzhavy i prava im. V. M. Koretskoho 2001) (in Ukrainian).

\section{Journal articles}

10. Petryshyn O, 'Forma derzhavnoho pravlinnia v Ukraini: do poshuku konstytutsiinoi modeli' ['Form of State Government in Ukraine: In Search of Constitutional Models'] (2014) 8 Pravo Ukrajiny (in Ukrainian).

11. Shapoval V, 'Vykonavcha vlada v Ukraini u konteksti formy derzhavnoho pravlinnia (dosvid pislia pryiniattia Konstytutsii Ukrainy 1996 roku)' ['Executive Power in Ukraine in a Context of the Form of the State Board (Experience after Accepting of the Constitution of Ukraine of 1996)'] (2016) 4 Pravo Ukrajiny (in Ukrainian).

\section{Роман Мартинюк}

кандидат політичних наук, доцент кафедри державно-правових дисциплін Навчальнонаукового інституту права ім. І. Малиновського Національного університету “Острозька академія"

\section{Roman Martyniuk}


candidate of Political Sciences, associate professor of the department of the state and legal fields of study of the Academic and Research Institute of Law named after Malynovskii of the National University "Ostroh Academy”

e-mail: roman.s.martyniuk@ukr.net 